\title{
New Directions in the History of Written Culture
}

\author{
Martyn Lyons \\ School of Humanities, University of New South Wales, Australia \\ e-mail: M.Lyons@unsw.edu.au
}

Received: 3 September 2012; Accepted: 3 October 2012; Published online: 8 January 2013

\begin{abstract}
This article reviews some new directions in the history of writing practices, concentrating on Western Europe and the Americas in the nineteenth and early twentieth centuries. I identify some major intellectual influences on the field, deriving from historiography, anthropology and literary studies. I indicate some important archives specialising in popular writings which sustain the study of the writings of ordinary and semi-literate people. A few selected topics in which the history of writing practices makes a contribution are then briefly reviewed. These are, firstly, the history of correspondence and letter-writing instruction manuals, which introduces two important concepts: the 'epistolary pact' and 'epistolary literacy'. Secondly, I introduce three new works on the development of postal services, stressing their role in forging national cohesion. Thirdly, I indicate how the study of emigrants' writings has contributed to a shift of focus in the study of emigration in general. I conclude that the history of scribal culture can make a significant contribution to socio-cultural history, provided that writing is analysed in its material form, and as a text, not simply as a source of information. Writing practices deserve serious study as a social and cultural phenomenon in their own right.
\end{abstract}

KEYWORDS: Correspondence; World War One; Emigration; Modern France; Modern Italy; Modern Spain

Citation / Cómo citar este artículo: Lyons, M. (2012) "New Directions in the History of Written Culture". Culture \& History Digital Journal 1(2): e007. doi: http://dx.doi.org/10.3989/chdj.2012.007

RESUMEN: Nuevas tendencias en Historia de la Cultura escrita.- Este artículo revisa algunas tendencias nuevas en la historiografía a propósito de las prácticas de escritura, concentrándose en Europa occidental y las Américas durante en el siglo XIX y principios del XX. Señalo en él algunas de las mayores influencias intelectuales que han incidido en este campo, provenientes de la historiografía, la antropología y los estudios literarios. Indico algunos importantes archivos especializados en escritura popular en los que se basa el estudio de los escritos de la gente corriente y semi-alfabetizada. Después reviso brevemente unos cuantos temas escogidos a los que ha hecho su aportación la historia de las prácticas de escritura: primero, la historia de la correspondencia y de las cartillas de instrucción para escribir cartas, que introducen dos importantes conceptos: el “pacto epistolar” y la "alfabetización epistolar"; en segundo lugar, presento tres nuevos trabajos sobre el desarrollo de los servicios postales, destacando su papel en la forja de la cohesión nacional; y en tercer lugar, indico cómo el estudio de los escritos de emigrantes ha contribuido a cambiar el enfoque en el estudio de la emigración en general. Concluyo que la historia de la cultura escrita puede proporcionar una contribución significativa a la historia socio-cultural siempre que la escritura sea analizada en su forma material, y como texto, y no simplemente como una fuente de información. Las prácticas de escritura merecen por derecho propio un serio estudio como fenómeno social y cultural.

PALABRAS CLAVE: correspondencia; primera guerra mundial; emigración; Francia contemporánea; Italia contemporánea; España contemporánea

Copyright: (C) CSIC. This is an open-access article distributed under the terms of the Creative Commons Attribution-Non Commercial (by-nc) Spain 3.0 License. 


\section{INTRODUCTION}

The origins of the history of the book, traditionally conceived, can be traced to 1958 , the publication date of Lucien Febvre and Henri-Jean Martin's pioneering L'Apparition du Livre. Febvre and Martin (1958) invited historians to consider books as objects of consumption, the products of a complex manufacturing process whose sale and distribution obeyed commercial imperatives and depended on established trade networks. More recently, the history of reading itself as a social and cultural practice has emerged, as the examination of readers and their responses have illuminated broader issues in European history. Investigating the ways readers appropriated and interpreted their texts has contributed, for example, to our understanding of the popular reception of the Protestant Reformation, and formed a central issue in the debate between Robert Darnton and Roger Chartier on the cultural origins of the French Revolution. The subject of this article, however, is an even newer offspring of the conventional histoire du livre: namely, the history of writing practices. Reading and writing have for a long time been treated separately by cultural historians, and there were good reasons for this. Until the nineteenth century, after all, they were distinct literary skills, taught independently of each other, and writing competence was always rarer than reading ability. If, however, we wish to study the history of letter-writing or of the private diary, the division between reading and writing no longer makes sense. In these genres, readers were writers and writers were readers. My purpose here is to briefly sketch some of the historiographical influences on the history of written culture, and to suggest some new directions in the field. I concentrate on the nineteenth century, with some excursions into the early modern period. My geographical focus is on western Europe and North America.

\section{GENEALOGY}

The Annales School is not the only avenue of approach to the history of writing practices; nor do all roads necessarily lead to Paris. Whereas French historiographical traditions were the chief inspiration of l'histoire du livre as well as of the history of reading, the history of writing has a different geography. Today we find important advances being made in this domain in Italy and in the Hispanic world. The history of writing practices and scribal culture demands a multi-disciplinary approach. It borrows something from micro-history, and is also sustained by the current trend towards revaluing individual and subjective experiences of the past. The field engages the expertise of cultural historians, palaeographers, ethnographers, sociologists, educators, and specialists in literary and in literacy studies. Armando Petrucci is an influential pioneer who married the skills of the palaeographer with broader trends in social and cultural history. Although his principal expertise lies in the study of writing and public inscriptions in Late Antiquity, his work is fundamental for the study of writing practices in any period (Petrucci, 1986, 2008). Petrucci's close attention to the materiality of documents is extended and continued in the work of Antonio Castillo Gómez, and his small but dynamic team of researchers at the University of Alcalá. ${ }^{1}$

In France, the approach has traditionally come from a different direction, partly because here palaeography has never been a university discipline, but instead is the speciality of the much-revered Ecole des Chartes. For French scholars, the inspiration of anthropology has been especially strong in the area of the history of writing practices. The influence of the Cambridge anthropologist Jack Goody is probably and paradoxically more pervasive in France than in the English-speaking world. ${ }^{2}$ What French scholars particularly take from Goody is his emphasis on writing as a 'technology of the intellect', a practice which shapes our thought processes into rational linear patterns, orders the memory and makes rapid information retrieval possible (Goody, 1986 among other titles). My own work, however, owes more to the Toulousebased ethnologist Daniel Fabre and his students. It was Fabre who first coined the now often-used phrase écritures ordinaires to categorise the writings of ordinary people (Fabre, 1993). I prefer Fabre's label of écritures ordinaires to roughly describe the writing of the semi-literate lower classes. Many other definitions are possible, and are frequently used by other scholars. In Britain and Sweden, the material is more usually known as 'vernacular writings'; in Germany and the Netherlands, scholars prefer the term 'ego-documents'. Neither label completely captures the lower-class association of écritures ordinaires, defined according to the humble status of the authors as the writings of 'ordinary' people.

The important and inspirational work of Philippe Lejeune defies disciplinary classification, and has no university home. His studies of autobiographical writings by adolescents, schoolgirls and individual diarists of all walks of contemporary life have brought about a major re-evaluation of ordinary writings, and they are marked by his passionate involvement and a profound respect for the writers themselves (Lejeune, 1989 among other titles). Lejeune would not be accepted as a literary critic, nor would he ever claim to be one. He is part sociologist, part cultural historian, and above all an animator of the Association pour l'Autobiographie, which collects and catalogues private writings, and organises discussions about them.

\section{THE IMPORTANCE OF WRITING}

Writing was once an instrument of oppression and a cultural practice confined to social and political 
elites; but by the end of the nineteenth century it had become indispensable at every level of European society. Handwriting is now a lost art, but in the late nineteenth and early twentieth centuries it served a range of essential functions. Writing by hand was essential for personal communication at a distance, for business transactions and for maintaining family networks. Faithful supplicants sent prayers to heaven in writing, while pastors and confessors recommended writing as part of the individual's spiritual development, so that self-writing became a crucial instrument in the examination of the Christian conscience. Subjects and citizens used writing to petition or insult their governments. Through writing, one managed family problems, conducted love affairs and tried to keep one's budget under control. In the twenty-first century, we are in danger of underestimating its importance, because the intense and widespread scribal culture of that period has all but disappeared. Today, personal writing has been relegated to a private and domestic universe of shopping lists and hastily scribbled mobile phone numbers. But in a world before telephones, e-mails and text messaging, writing sustained daily life and human contact. The résumés of today's job applicants list their skill and experience with the latest computer software programmes; but their nineteenth-century equivalents had to demonstrate good handwriting as the essential professional asset for any clerical or professional employment. In the 1840 s, for example, the future American novelist Herman Melville could not get a job in Manhattan because his handwriting was too poor (Augst, 2003: 219). Men away on business trips wrote home daily, soldiers in the trenches wrote almost as frequently to their relatives and loved ones, and emigrants across the oceans kept in contact with their family of origin through writing. Middle-class spouses even wrote to each other when they were not separated, the husband having notes delivered to his wife while she was busy in another room of their spacious residence.

Until recently, however, only the writings of educated people attracted the serious attention of cultural historians. The private correspondence of bourgeois families revealed their extended networks, their inner dynamics and the issues which concerned them. The study of letters has thrown new light on the different roles and responsibilities of middle-class men and women in sustaining family relationships (Dauphin et al., 1995). Similarly, the proliferation of private journals in nineteenth-century European society helped to focus attention on the role of writing in the development of the individual personality. Feminist scholars were in the forefront of the study of diaries and journaux intimes, investigating the development of female individuality and gendered selfrepresentation (Bunkers and Huff, 1996; Sinor, 2002).

These studies have usually been confined to the writings of social strata for whom writing came easily. For the educated middle classes, writing was a familiar cultural practice in which they had been well trained. They had mastered the technology of writing, its materials and instruments and the physical discipline required to make use of them. They knew how to manipulate a quill or later a steel pen, how to apply the ink without smudging the page, how to write in a straight line, constructing sentences and paragraphs, and how to dry the ink later with sand or finely ground shell. Writing letters to other correspondents from various ranks involved social protocols in which they had been thoroughly educated. Rarely, until now, has the same spotlight been directed at the writings of the semi-literate and partly educated. Illiterate people, too, were writers with the help of intermediaries, and they also were part of the scribal culture of the poor. The correspondence of peasant soldiers in the trenches during the First World War demonstrates some essential characteristics of ordinary writings. Punctuation was used randomly and often not at all. Wordseparation was haphazard, and dialect and oral speech strongly influenced their writing. We cannot expect semi-literate writers to show a good grasp of the syntax or spelling of their national language, especially when this was not always familiar to them. Their writing style borrowed from their brief and rudimentary schooling and from the bureaucratic speech they had learned in the army. And yet, in an emergency, soldiers found a way to write home.

\section{ARCHIVES}

Two momentous events made a fundamental impact on the cultural lives of ordinary people in the late nineteenth and early twentieth centuries. These were firstly, the beginning of mass emigration across the oceans, particularly to the Americas, and secondly, the First World War. Quite apart from the enormous social and economic repercussions of these events, they both generated a seismic cultural shift: they produced a massive outpouring of letter-writing amongst people who were barely literate and totally unaccustomed to handling a pen. The prolonged and painful separation of loved ones and family members caused by the extraordinary circumstances of war and emigration made writing essential. Writing was needed to hold families together and manage their collective affairs. Through writing, individuals worked from a distance to sustain their social identities as members of a family group. This enormous corpus of popular writing was a writing of absence and desire the desire to return to one's loved ones, to familiar surroundings and to the stable co-ordinates of a world which was irretrievably disappearing. In the First World War, it was also a writing of survival -'writing to stay alive' (scrivere per non morire) was how the Italian soldier Francesco Ferrari put it (Croci, 1992). Writing was synonymous with existence itself.

In the last thirty years, a number of specialist archives have emerged specifically devoted to the 
writings of ordinary people, and initiatives in Italy and Spain have led the way. In Spain, Antonio Castillo Gómez and Verónica Sierra Blas at the University of Alcalá de Henares co-ordinate a loose network of such institutions. Many such archives, like the small one at La Roca del Vallès near Barcelona, are inspired by left-wing democratic aspirations and also by regionalism - in this case Catalan (García Lorenzana, 2001). Similarly, the archive of Asturian emigration in Gijón resides in the Museo del Pueblo de Asturias, dedicated to that region's cultural heritage. In the Nordic countries, folklore studies have provided a strong impetus for the collection of writings by farmers and peasant intellectuals. The Finnish Literature Society, established in 1831, solicited and collected ordinary writings as expressions of a national identity rooted in folk traditions. Various Italian centres offer invaluable materials to the historian of everyday writing practices, including the Archivio Ligure della Scrittura Popolare in the University of Genova, the Archivio della Scrittura Popolare di Trento, attached to the Italian War Museum, and the Archivio Diaristico Nazionale in Pieve Santo Stefano, dedicated to fostering life-writing (Iuso, 2002, 2001). All these new archives of popular writing are subtly different, but they all express a political agenda. They exist to promote respect for popular writings, to validate popular memories, and to offer a radical alternative to the official records found in other administrative and institutional depositories.

Many other projects reinforce the new interest in the intimate or family writing of people of modest social origins, although it is impossible to discuss them all in detail here. Jean-Pierre Bardet and François-Joseph Ruggiù maintain a website and publish studies related to their French project on 'Les écrits du for privé' (Bardet and Ruggiù, 2005). Raul Mordenti, specialist in libri di famiglia at the University of Rome Tor Vergata, is director of the Biblioteca Informatizada de Libros de Famiglia and editor of the electronic journal Testo e Senso. ${ }^{3}$ Nordic networks have been particularly active in this area: Finnish scholars are developing a project entitled 'The Common People and the Processes of Literacy in the Nordic countries', while another group at the University of Umeå in Sweden are researching 'vernacular literature - a diachronic perspective on literacy in Sweden and other Nordic countries'. The project led by Rudolf Dekker and Arianne Baggerman in Rotterdam on ego-documents in the Netherlands during the early modern period has inventoried thousands of Dutch diaries and analysed them from the point of view of their authors' conceptions of time. This collection is not confined to the diaries of lowerclass authors, and unfortunately for my own purposes, it does not yet extend beyond 1814 (Dekker, 2002).

The study of written culture is therefore booming, and it is impossible in this short article to convey its full scope and potential. What follows is a review of some selected themes or genres.

\section{LETTER-WRITING AND EPISTOLARY LITERACY}

Personal correspondence has often been exploited by historians, to give evidence about daily life or to support a biography. But until quite recently, letterwriting has rarely been considered in its own right, as a social and cultural phenomenon with its own codes, rituals, grammar and rhetoric. The French historian Cécile Dauphin has probably contributed more than anyone to a new consciousness of the significance and underlying rules of letter-writing in the modern period. Her exemplary study of the voluminous Mertzdorff family correspondence, including over 3,000 letters written between 1795 and 1933, emphasised the crucial role of letter-writing in performing and perpetuating family networks and solidarities (Dauphin et al., 1995). Correspondence kept families together and defined their internal dynamics. About half the letters in the Mertzdorff correspondence were exchanged between parents and children. About ten per cent were letters between spouses, who normally corresponded with each other daily when separated by the husband's business trips. Regular and energetic letter-writing strengthened a dense fabric of relationships within bourgeois families, between spouses, parents and children, and between siblings and cousins.

Although we tend to think of personal correspondence as an intimate genre, this was far from the case in nineteenth-century Europe. Courting rituals and family solidarities prevented love letters from being privately written or privately received. Letters between a courting couple were customarily overseen by the girl's mother and they had to pass through her hands. The Mertzdorff corpus includes letters with multiple authors, letters with multiple recipients, and letters designed to be copied and read aloud to the family. The concept of individual privacy was hardly recognised; family networks ensured that written communications were collectively owned.

Correspondence is a highly coded form of writing, obeying and applying unspoken rules and formulas. Armando Petrucci's masterly survey of the history of the letter over several centuries shows how enduring its essential structure has been (Petrucci, 2008). Since antiquity, letters have always had a tripartite form, made up of the greeting, the body of the letter and a farewell. In all periods, letter-writing has been a shared ritual which relies on an implicit agreement between the correspondents. This is what Dauphin calls 'the epistolary pact', a contract to which letterwriters tacitly subscribe. Assumptions or negotiations are made about the length of letter expected, the appropriate forms of address and farewell, the subjects to be broached and those which are taboo. The epistolary pact can be discerned even in the choice 
of paper, its quality and format, and the colour of the ink. The amount of blank space left at the head of the page before the first words of greeting, for example, was a measure of deference and hierarchy. All these material aspects indicate something about the relationship between correspondents.

In spite of the letter's enduring structure, a few things changed in the nineteenth century. The envelope was invented, making seals obsolete and providing greater secrecy in transit. The prepaid postage stamp, adopted first in Britain in 1840 and thereafter elsewhere, meant that the recipient of a letter was no longer burdened with payment on delivery. Coloured paper and coloured inks were commercially available, and the cheap steel pen was rapidly adopted. For the first time, at least in the letters of the educated bourgeoisie, correspondents wrote in paragraphs which were consistently indented (Petrucci, 2008: 130-1).

Writers nevertheless had to learn how to use the unspoken formulas of correspondence, and they needed an apprenticeship, too, in the technology of writing. According to Susan Whyman, families of the 'middling sort' had already acquired a letter-writing culture in eighteenth-century Britain. Whyman usefully refers to the idea of 'epistolary literacy' to describe everyday letter-writing practices which a generation ago were taken for granted. Epistolary literacy embraces the ability to produce good quality handwriting, a mastery of the technology of writing and its materials, control of the layout of the page, the techniques of sealing and addressing, as well as familiarity with the postal services. It was demonstrated by punctuation, indented paragraphs, capitalisation, margins and a flourished signature (Whyman, 2009: 9-11).

Epistolary literacy, however, was highly gendered, and women did not have the same skills as men. In spite of the conventional association of letter-writing with female intimacies, this is a distortion of the truth: the vast bulk of letters in the modern and early modern period were written by men. A survey of 158 million postal items franked in France in 1849 suggested that purely personal correspondence may have amounted to a mere ten per cent of the total (Dauphin, 1995: 92-3; Chartier, 1991).

In the nineteenth century, it was increasingly necessary to master the codes and techniques of letter-writing, to woo a lover, to keep in touch with absent family members, to search for employment, to manage personal relationships, or just for pleasure. Towards the end of the century, cheap etiquette books and letter-writing manuals, designed to assist the aspiring correspondent, proliferated. Evolving from aristocratic models of civility, letter-writing had now fully democratised its courtly heritage. Historians have produced several studies of such manuals in France, Italy and Spain (Dauphin, 2000; Tasca, 2002; Sierra Blas, 2003). They regard letter-writing manuals as sources of social and cultural history. They indicate ways in which letter-writing is embedded in social and gender relations, and in the ways individuals defined themselves and their roles in society. In Franco's Spain, letter-writing manuals sought to inculcate respect for authority and the family, religious morality and a sense of social hierarchy. On the republican side during the Civil War, teaching letter-writing was part of the ideological struggle against fascism, as the Republic tried to educate its illiterate soldiers. In almost every context, letter-writing manuals reveal the norms of gendered behaviour, and promote an ideal of romantic love leading to marriage. Men were advised to use white and never coloured paper, and it was best for them to stick to black rather than violet or purple ink. Invariably in the manuals men are expected to make declarations of love and request an answer, and men are expected to initiate reconciliation after a quarrel. Invariably women are expected to make the decision about whether a relationship can begin or not. Letter-writing manuals continued to perform a moralising and a socialising function, acculturating the semi-literate to the norms of written intercourse. In the nineteenth century, as Cécile Dauphin discovered, letter-writing seemed to sustain the entire social fabric.

\section{THE RISE OF NATIONAL POSTAL SERVICES}

Victorian Britain, argues Catherine Golden, witnessed a letter-writing revolution. This slightly overblown assertion, developed somewhat repetitively in her recent book, rests entirely on Rowland Hill's introduction of the Penny Post in 1840. Golden's work has the merit of highlighting the discussions and fears surrounding this important innovation. The Penny Post, she argues, created the Victorian equivalent of the internet, in other words, it constituted a communications revolution which enabled people to stay connected (Golden, 2009: 240). Like the Internet, it engendered great optimism as well as great anxiety. Cheap postage, it was thought, would encourage immorality, allowing couples to organize secret rendezvous, fostering clandestine correspondence between unsuitable lovers, now protected by the anonymity of the pillar-box. Cheap postage opened up new opportunities for criminal mischief, junk mail, blackmail and slander, spam and scam.

A national postal service, however, can be considered as one of the essential nation-building institutions, a communications infrastructure which allowed individuals to identify themselves with new and wider communities. In this sense, the study of the history of writing becomes the study of the public sphere and of national consciousness. According to James How, the foundation of a Post Office in England in the 1650s opened up new 'epistolary spaces', in the same way as the Internet opened up new 'cyberspaces' (historians of written culture clearly love their Internet analogies) 
(How, 2003: 1-7). The growth of postal services created greater traffic in news, which fostered the extension of the public sphere. It enabled individuals to keep in touch with public affairs and created a new space for action. The Post Office made a difference because it was an integrated system, based on a set of advertised routes, offering a continuous service. Of course it also created a higher risk of government surveillance and mail interception as a result; but the way was open to experiment in all that a correspondence could achieve: it opened up new forms of petitioning the state and the aristocracy; novels like Richardson's Clarissa, with which How is inordinately concerned, suggested that a whole life could be lived in an epistolary space.

Constantin Dierks' study gives us a richer and more sophisticated treatment than either Golden or How. His view of letter-writing and postal communication across the Atlantic is linked to the eighteenthcentury consumer revolution, to middle-class commercial expansion, and at the same time to the operations of Empire (Dierks, 2009). American letter-writing, according to Dierks, expressed middleclass white supremacy, and its ideologies of self-improvement, imperialism and competitive consumer capitalism. By the early eighteenth century, he stresses, Britain developed a new communications infrastructure, which was an instrument of bureaucratic culture and imperial power. Postal services became bureaucratised instead of being 'out-sourced' to contractors or aristocratic monopolies. A road system emanating like spokes from London was improved, based on six post roads connecting with packets to Europe, and financed through the turnpike system by the road users themselves. These changes were touted as the epitome of modernity and the vital sinews of commerce. The Postal Act of 1711 integrated the colonial seaboard into a fully-fledged imperial postal service.

It was thus significant that in 1774-1775, before the War of American Independence actually broke out, the colonists took over the imperial postal system, which was then made up of 64 Post Offices stretching between Falmouth (Maine) and Savannah (Georgia). Letters coordinated the American war effort, and it was important to control their distribution and protect their safety. The control exerted by imperial postmasters was already under attack because it infringed the free circulation of newspapers, and postal charges were seen as yet another example of British 'taxation without consent' (Dierks, 2009: 195-6). The Continental Congress based the new American postal system in Philadelphia, since New York had been abandoned to the British, and appointed Ben Franklin as first postmaster. Control of an effective postal service was thus essential to the emergence of an independent United States. George Washington and his staff signed 12,000 letters between 1776 and 1783, when he resigned his command (Dierks, 2009: 214).
Washington's army was steeped in documentary culture and was the centre of a new and effective postal infrastructure. Letter-writing was not just the sinew of commerce and the beacon of modernity; it was also a crucial instrument of political control and national cohesion.

\section{THE WRITING OF EMIGRATION}

War and emigration both engendered a boulimic explosion of popular writing in the half-century between 1870 and 1920. Here I will focus on the writings of emigration, from which have emerged new perspectives on the emigrant experience. Take the example of Spanish emigrants to the Americas in the late nineteenth century, many of them young teenage boys who had little if any formal schooling. Literacy was vital to Spanish emigrants, not least because it enabled them to write home and maintain a presence in their native community. Pedro Jado Agüero knew this well, and advised his two sons to improve their skills. Pedro's son Ezequiel had left Spain for Cuba in 1870, and his father admonished him to use his leisure time to improve his cursive hand and to broaden his reading in order to learn to spell correctly (Rubalcaba Pérez, 2004: 477; Blasco Martínez and Rubalcaba Pérez, 2003: 109). Writing was not only important as a lifeline to the home country, but it was also essential for taking advantage of employment opportunities in business and retail shop-keeping. If emigrants arrived in the Americas as illiterates, they immediately saw the need for a crash course in reading and writing. As Antonio Gibelli put it, they acquired an 'emergency literacy', which was often imitative of business writing models. Their career and their identities depended on writing, and Asturian emigrants in particular were to make an extraordinary investment in primary education in their home province. The next generation would not leave home ill-equipped, if they could possibly help it.

Emigrants were uprooted from family and community. They tried to preserve some continuous connection with these roots because they were fundamental to their social identity. In their new country, however, migrants fashioned new identities for themselves. They acquired new cultural practices, new connections and in time if necessary a new language. Yet at the same time, they remained attached to home and their former selves. Their correspondence gives us clues about the problems and ambivalences of developing new individual identities in the diaspora. The focus of inquiry in migration studies has shifted: measuring factors of integration and assimilation is no longer a priority; instead, the many facets of transnational identities are attracting scholarly attention. This makes it easier to envisage emigrant identities from different angles and to accept that they might have double or even triple dimensions. The letters they 
wrote home created a transnational arena in which their changing identities were transacted.

Historians have been accustomed to mining emigrants' correspondence for very specific data. The data they extracted was testimony about the nature of life in America, about the material problems of emigrants and about how these problems were overcome. They were not interested in the letters as data about themselves, that is to say about the history of ordinary writings and the spread of epistolary practices. They sometimes made a further error in regarding the data in the letters as objective information about American society. Using this perspective, they could construct a story in which the emigrant, initially faced with hardships, managed to overcome them and successfully integrate into American life. Yet emigrants' letters can never be taken entirely at their face value. They are full of rhetoric and ruse. When they exaggerate the hardships of their new life, they do so for a reason, to explain why they are sending an 'empty' letter, in other words a letter containing no remittances. When they celebrate their successes, they do so in part to justify the decision to leave home in the first place. There is nothing completely innocent about these devices. Alfonso Camín, looking back much later, remembered the words of a fellow-emigrant in $\mathrm{La}$ Quinta de Covadonga (Cuba):

\footnotetext{
'Why? We emigrants have to keep our troubles to ourselves. You never send bad news to Spain. Here we all succeed. Even those of us who are dead. You understand?' (cit. Martínez Martin, 2011: 123-46).
}

Emigrants developed a heroic narrative on which heritage historians subsequently built. Emigrants' letters and their editors constructed a social memory of emigration, in which the emigrant triumphed over suffering and successfully entered a new civic community.

The study of emigrants' ordinary writings therefore laboured under several burdens which had to be progressively set aside. There was, firstly, the burden of a social science approach wedded to the quantitative study of the movement of peoples across the oceans, in which the individual emigrant appeared only as an identikit figure composed of statistical averages. New perspectives on the emigrant experience now offer to examine individual cases and to respect individual choices. Instead of being swamped in a macro-economic approach to the causes and consequences of migration, the emigrants emerge as agents of their own destiny, making their own personal decisions. Thus in El baúl de la memoria, a title which refers to the chest in which emigrants typically carried their personal belongings, the authors re-evaluated the subjective element of the Italian migrant experience in Peru. In place of a globalizing interpretation, they examined personal sources to reveal the expectations and emotions which played an important role in the emigration process (Croci and Bonfiglio, 2002). Similarly, Antonio Gibelli invites a view of the emigration experience from within, that is to say from the private writings of individual emigrants themselves. In this perspective, he argues, America is not a promised land, but a resource, one of several that peasant families had at their disposal (Gibelli, 1994: 589).

A further burden on the study of emigrants' letters was the failure of historians to accept or even to notice the potential interest of the letter-writing phenomenon itself. Emigrant letters seem to enact a form of theatre, often opening with an elaborate greeting and finishing with a long list of recipients to whom the writer wished to be remembered. Many historians and editors of collections of letters, however, failed to confront and understand the form of the letter and the significance of the performance rituals embedded in the correspondence, which functioned to maintain the presence of the absent author within a social group. Two exceptions to this criticism are David Gerber's analysis of the letters of literate, Protestant, British emigrants to the USA and Canada, and David Fitzpatrick's meticulous study of Irish emigrants' correspondence from Australia (Gerber, 2006; Fitzpatrick 1995: 473-6). Although both these authors work exclusively within an English-language historiography, they were careful to analyse the epistolary exchange itself, or what Gerber rather ponderously called 'immigrant epistolarity'. Fitzpatrick's attention to the rhetoric of greetings as well as to the presence of oral forms in the text was unusual. His only mistake was to assume that the very formal structure of the letters was a particularly Irish characteristic, whereas it was a feature of ordinary writings of this period in general. ${ }^{4}$ Furthermore, the potential contribution of emigrants' ordinary writings to a new history from below is now being eloquently recognized. Fitzpatrick significantly interpreted Irish letters from Australia as 'the forgotten vernacular of the steerage classes' (Fitzpatrick, 1995: 29). In similar vein, Emilio Franzina claimed that the letters of Venetian peasants in South America were the ingredients of an alternative history of the subordinate classes (Franzina, 1979). My contention is therefore twofold: that the correspondence of emigration illuminates both the history and expansion of letter-writing practices amongst ordinary writers; and that it offers insights into the individual and subjective experience of emigration itself. This is not because emigrants' letters are especially authentic or spontaneous: as I have remarked, they frequently doctored the truth, in constructing what Gerber calls their 'identity narrative'. But even these disguises formed part of their adoption of a new identity in the diaspora. 


\section{CONCLUSION}

This short article is not intended to be a comprehensive survey of recent work in the history of writing. Instead, I have indicated just a few interesting directions currently taken by historians in this domain of cultural history. I have not included discussion on other, perhaps equally fruitful lines of inquiry. These would include the writings of war, pursued recently by Martha Hanna and myself, in the context of letters written to and from the French and Italian trenches in the First World War (Hanna, 2003, 2006; Lyons, 2003, 2012). Whereas Hanna is impressed by frank and candid exchanges between spouses and lovers, my own emphasis is rather on the inherent silences of the letters and their attempts to disguise the truth of the trench experience. I have also omitted the study of school exercise books and the burgeoning field of children's writing in general. I have thus neglected the harrowing tale told by Verónica Sierra Blas in her study of letters written home by children evacuated to the Soviet Union during the Spanish Civil War. Many of their letters never reached their families in Spain; they were intercepted by the Francoist regime in order to identify and incriminate republican supporters - and this sinister reason is why the letters have survived in their Salamanca archive (Sierra Blas, 2009). I have also side-stepped any treatment of the specific cultures of graffiti and of prison writing, imaginatively treated by Philippe Artières and others (Artières, 2000; Castillo Gómez and Sierra Blas, 2005).

The selected works reviewed here do show, I suggest, that the history of writing can illuminate important aspects of the socio-cultural history of nineteenth and early twentieth-century Europe, under two conditions. The first is that writing is studied for itself, not simply as a source of information or purely as testimony, but as a social and cultural phenomenon in its own right. The second proviso is that historians cease to assume that peasants and workers were too illiterate or inarticulate to leave written traces of their existence. This assumption is erroneous. Historians of writing are now beginning to outline the contours of a submerged continent of ordinary writings. War and emigration produced exceptional circumstances of separation in which writing became intrinsic to the lives of ordinary people. In at least three mainly peasant societies - France, Spain and Italy - the transition to mass literacy was marked by an explosion of writings by the partly educated and semi-literate. Italy, during 31/2 years of war, produced 4,000 million items, in spite of the fact that $35 \%$ of Italians were officially illiterate (Gibelli in Castillo Gómez, 2002). France, which also had a mostly-peasant army, produced about 10,000 million postal items in the First World War, and Germany at least 30,000 million. I have qualified this explosion as 'boulimic'; the historian of Portuguese emigration to Brazil, Henrique
Rodriguez, prefers to call it 'compulsive writing', but we are both describing the same phenomenon. ${ }^{5}$ Even the most untutored writers overcame their difficulties, making a time and a space to write. They apologized profusely for their epistolary faults, but having grasped a pencil and improvised some writing materials, they appropriated the page in front of them for their own purposes. They wrote out of an urgent need to remind loved ones that they were still alive, they wrote to remember and make sense of extraordinary experiences or they wrote simply for the pleasure of writing. They used writing to record, to communicate and to manage distant affairs of the family. They wrote to ingratiate themselves with superiors, and to construct or preserve an identity. As a few explicitly realized, writing became an inseparable part of life itself.

It no longer seems legitimate to assume that the poor and uneducated were inarticulate or that they have left few written traces of their existence with which historians can work. In the nineteenth century at least, otherwise unremarkable people left abundant written testimonies, and even what has been conserved contains only a small fraction of their astronomical output. The creation over the last quarter of a century of an archipelago of archival collections of popular writing has made these testimonies available for study.

Ordinary authors may have been unaccustomed to the art of writing, but they quickly realized its value. The Danish peasant Søren Pedersen Havrebjerg fought in the Napoleonic Wars and wrote a diary in which he noted income and expenditure, recorded changes in the weather and the state of the harvest. Writing, he felt, had saved him from the evils of drink and bad company, and he was proud that he had been able to write home to his parents without paying someone to do it for him. He wrote in his diary in 1809:

\footnotetext{
'Yes, next after reading, this art of writing has for me been the most useful, the most pleasant, consoling, encouraging activity in the whole world' (Markussen, 1990: 63).
}

I hope I have indicated the presence and scale of this neglected territory, and to show that writing was of utmost importance to people such as Havrebjerg, people of humble birth who were illiterate or who had received only a smattering of education.

\section{NOTES}

1. A full bibliography is impossible here, but contemporary Spanish work is best approached through the journal Cultura Escrita y Sociedad at http://www.siece.es/siece/revista.html [accessed 12/September/2012], and the website of the Seminario Interdisciplinar de Estudios sobre Cultura Escrita (SIECE) at http://www.siece.es [accessed 12/September/2012].

2. An exception to this generalisation is Michael Clanchy, whose excellent book has a very Goody-esque title (Clanchy, 1983).

3. http://testoesenso.it [accessed 15/September/2012]

4. Fitzpatrick later modied his previous assumptions (Fitzpatrick, 2006). 
5. Henrique Rodriguez, unpublished paper to conference on 'Escritas de Mobilidade', Centro de Estudos de Historia do Atlántico, Madeira, June 2011. 'Boulimia' echoes Bacconnier, (1985: 17)

\section{REFERENCES}

Artières, Philippe (2000) La vie des coupables. Autobiographies des criminels, 1896-1909, Albin Michel, Paris.

Augst, Thomas (2003) The Clerk's Tale: Young Men and Moral Life in Nineteenth-Century America, Chicago University Press, Chicago.

Bacconnier, Gérard; Minet, André and Soler, Louis (editors) (1985) La plume au fusil: les poilus du Midi à travers leur correspondance, Privat, Toulouse.

Bardet, Jean-Pierre and Ruggiù, François-Joseph (editors) (2005) Au plus près du secret des caurs? Nouvelles lectures historiques des écrits du for privé en Europe du XVIe au XVIIIe siècle, Presses de l'Université Paris-Sorbonne, Paris.

Blasco Martínez, Rosa Maria and Rubalcaba Pérez, Carmen (2003) $<$ Para hablarte a tan larga distancia ...> Correspondencia de una familia montañesa a ambos lados del Atlántico, 18551883, Estudio, Santander.

Bunkers, Suzanne L. and Huff, Cynthia A. (editors) (1996) Inscribing the Daily: Critical Essays on Women's Diaries, Massachusetts University Press, Amherst MA.

Castillo Gómez, Antonio (editor) (2002) La conquista del alfabeto: Escritura y clases populares, Trea, Gijón.

Castillo Gómez, Antonio and Sierra Blas, Verónica (editors) (2005) Letras bajo sospecha, Trea, Gijón.

Chartier, Roger (editor) (1991) La Correspondance. Les usages de la lettre au XIXe siècle, Fayard, Paris.

Clanchy, Michael T. (1983) From Memory to Written Record: England, 1066-1307. 2nd ed. Blackwell, Oxford.

Croci, Federico (1992) Scrivere per non morire: lettere della Grande Guerra del soldato bresciano Francesco Ferrari, Marietti, Genova.

Croci, Federico and Bonfiglio, Giovanni (2002) El baúl de la memoria: Testimonios escritos de inmigrantes italianos en el Perú, Fondo editorial del Congreso del Perú, Lima.

Dauphin, Cécile (1995) 'Pour une histoire de la correspondance familiale', Romantisme, 90: 89-99. http://www.persee.fr/web/ revues/home/prescript/article/roman_0048-8593_1995_num_25 903055 [accessed 15/September/2012]

Dauphin, Cécile; Lebrun-Pézerat, Pierrette and Poublan, Danièle (editors) (1995) Ces Bonnes Lettres: une correspondance familiale au XIXe siècle, Albin Michel, Paris.

Dauphin, Cécile (2000) 'Prête-moi Ta Plume...': les manuels épistolaires au XIXe siècle, Kimé, Paris.

Dekker, Rudolf (editor) (2002) Egodocuments and History: Autobiographical Writing in its Social Context since the Middle Ages, Verloren, Hilversum.

Dierks, Konstantin (2009) In My Power: Letter Writing and Communications in Early America, University of Pennsylvania Press, Philadelphia.

Fabre, Daniel (editor) (1993) Écritures ordinaires, POL/Centre Georges Pompidou, Paris.

Febvre, Lucien and Martin, Henri-Jean (1958) L'Apparition du livre, Albin Michel, Paris. http://dx.doi.org/10.1522/030077 547

Fitzpatrick, David (1995) Oceans of Consolation: Personal Accounts of Irish Migration to Australia, Melbourne University Press, Melbourne.

Fitzpatrick, David (2006) 'Irish Emigration and the Art of LetterWriting'. In Letters across Borders: The Epistolary Practices of International Migrants, edited by Elliott, Bruce S.; Gerber, David A. and Sinke, Suzanne M., Palgrave-Macmillan, Basingstoke UK and New York, pp. 97-106.

Franzina, Emilio (1979) 'Merica! Merica!' Emigrazione e colonizzazione nelle lettere dei contadini veneti in America Latina, 1876-1902, Feltrinelli, Milan.
García Lorenzana, Francisco (2001) 'Conjurar el olvido: Archivos de la Memoria Popular'. In Cultura escrita y clases subalternas: una mirada española, edited by Castillo Gómez, Antonio, Sendoa, Oiartzun, pp. 191-206.

Gerber, David A. (2006) Authors of Their Lives: The Personal Correspondence of British Immigrants to North America in the Nineteenth Century, New York University Press, New York.

Gibelli, Antonio (1994) 'La risorsa America'. In Storia d'Italia, Le regioni dall'Unità a oggi. La Liguria, edited by Gibelli, A. and Rugafiori, P., Einaudi, Turin.

Golden, Catherine J. (2009) Posting It: The Victorian Revolution in Letter-Writing, University Press of Florida, Gainesville FL.

Goody, Jack (1986) The Logic of Writing and the Organization of Society, Cambridge University Press, Cambridge UK.

Hanna, Martha (2003) 'A Republic of Letters: The Epistolary Tradition in France during World War 1', American Historical Review, 108: 1338-1361. doi: http://dx.doi.org/10.1086/ 529969

Hanna, Martha (2006) Your Death Would be Mine: Paul and Marie Pireaud in the Great War, Harvard University Press, Cambridge MA.

How, James (2003) Epistolary Spaces: English Letter Writing from the Foundation of the Post Office to Richardson's Clarissa, Ashgate, Aldershot UK

Iuso, Anna (2000) 'Per una genealogia europea'. In Vite di carta, edited by Antonelli, Quinto and Iuso, Anna, L'Ancora, Naples, pp. $13-30$.

Iuso, Anna (2001) 'Europa autobiographica', Genesis, 16: 220-31.

Lejeune, Philippe (1989) 'Cher cahier...': témoignages sur le journal personnel, NRF-Gallimard, Paris.

Lyons, Martyn (2003) 'French Soldiers and their correspondence: towards a history of writing practices in the First World War', French History, 17: 79-95. doi: http://dx.doi.org/10.1093/fh/ 17.1.79

Lyons, Martyn (2012) The Writing Culture of Ordinary People, c. 1860-1920, Cambridge University Press, Cambridge UK

Markussen, Ingrid (1990) 'The Development of Writing Ability in the Nordic Countries in the Eighteenth and Nineteenth Centuries', Scandinavian Journal of History, 15: 37-63. doi: http://dx.doi.org/10.1080/03468759008579189

Martínez Martin, Laura (2011) 'Letras en la distancia: escritura epistolar y emigración en Asturias, 1899-1932'. In Amarras de tinta. Emigración transoceánica e escrita popular na Península Ibérica, séculos $X I X-X X$ edited by Núñez Seixas, Xosé Manoel and González Lopo, Domingo L., Universidad de Santiago de Compostela, UNESCO and Consello da Cultura Galega, Santiago de Compostela, pp. 123-46.

Petrucci, Armando (1986) La Scrittura: ideologia e rappresentazione, Einaudi, Turin.

Petrucci, Armando (2008) Scrivere lettere: una storia plurimillenaria Laterza, Rome.

Rubalcaba Pérez, María del Carmen (2004) 'Prácticas de Cultura Escrita: Aproximaciones y Realidades. Provincia de Santander, siglo XIX', unpublished doctoral thesis, Universidad de Cantabria. http://hdl.handle.net/10803/10656 [accessed 15/ September/2012]

Sierra Blas, Verónica (2003) Aprender a escribir cartas: los manuales epistolares en la España contemporánea (19271945), Trea, Gijón.

Sierra Blas, Verónica (2009) Palabras Huérfanas. Los niños y la Guerra Civil, Taurus, Madrid.

Sinor, Jennifer (2002) The Extraordinary Work of Ordinary Writing: Annie Ray's Diary, Iowa University Press, Iowa City.

Tasca, Luisa (2002) 'La corrispondenza "per tutti', I manuali epistolari italiani tra Otto e Novecento', Passato e Presente, 55: $139-58$.

Whyman, Susan E. (2009) The Pen and the People: English Letter Writers, 1660-1800, Oxford University Press, Oxford. 